\title{
Exploring the Origin, Definition and Measurement of Organizational Ambidexterity
}

\author{
Hang WU \\ Business School, East China University of Political Science and Law, Shanghai 201620, China \\ wuhang0503@163.com
}

\begin{abstract}
Keywords: Organizational ambidexterity, Structural ambidexterity, Behavioural ambidexterity, Realized ambidexterity.
\end{abstract}

\begin{abstract}
Organizational researchers are using ambidexterity, the ability of humans to use both hands with equal skill, as a metaphor for organizations that are equally dexterous at exploitation and exploration. Existing definition of organizational ambidexterity can be divided into three categories: structural ambidexterity, behavioral ambidexterity and realized ambidexterity. Scholars based on the balance view believe that organizational ambidexterity is mainly measured by the absolute value of the difference of competing strategic behavior, while scholars based on the integration view believe that organizational ambidexterity is mainly measured by the product of competing strategic behavior.
\end{abstract}

\section{Introduction}

Increasingly, organizational researchers are using ambidexterity, the ability of humans to use both hands with equal skill, as a metaphor for organizations that are equally dexterous at exploiting and exploring. Achieving ambidexterity means that an organization can implement exploration and exploitation simultaneously. Researchers has applied the ambidexterity view to a lot of theoretical fields, such as technological innovation, organizational learning, strategic management, external knowledge search, internationalization, and so on. This paper mainly uncovers the origin, definition and measurement of organizational ambidexterity.

\section{The Origin of Organizational Ambidexterity}

One of the core perspectives of organizational research is that different organizational strategies and environmental conditions require different forms of organization. For example, Burns and Stalker [1] argue that companies operating in a stable environment will develop a mechanical management system that hierarchical relationship is clearly defined, work definition is clearly defined, and employee's role is clearly defined. In contrast, enterprises in a dynamic environment will develop more organic organizational systems that characterized by the lack of formal definition of the task, do not rely on formal and standardized management system, have more horizontal coordination mechanism. Subsequent research confirms this view, and researchers generally agree that different organizational structures match different organizational strategies and environments.

Based on this view, scholars in the field of organizational adaptation argue that an organization needs to change its organizational structure in order to successfully cope with the dynamic external environment and obtain long-term competitiveness. Thompson [2] defines this trade-off between efficiency and flexibility as a management paradox. March [3] argues that the challenge for companies to adapt is the need to leverage existing assets and capabilities and to carry out enough exploration activities to adapt to changes in the technology and market environment. In his view, exploitation activity related to efficiency, control, certainty, and reduction of discrepancies, and exploration activity related to search, discovery, autonomy and innovation. In the view of March [3], the basic problem faced by enterprises is to implement sufficient exploitation activities to protect the current viability of enterprises, while implementing adequate exploration activities to ensure the viability of enterprises in the future. However, March [3] also points out that it is difficult for firms to strike a balance between exploitation and exploration activities, as most firms prefer to focus on 
short-term success. Exploratory activities are inherently ineffective and inevitably produce a lot of useless ideas. However, if the enterprise is only concerned with the exploitation activities, but not involved in the exploration activities, then when the external environment makes major changes, companies are likely to be extruded out of the market.

Based on the logic that exploration and exploitation activities require different organizational structures, scholars argue that organizations must have both structures in order to maintain long-term competitiveness. For example, Duncan [4] argues that firms need to switch between innovation generation and innovation utilization. After conducting a survey of some firms, Tuchman and O'Reilly [5] suggest that organizations need to simultaneously explore and exploit, as a dualistic organization. This view has led scholars to discuss ambidexterity and enterprise performance, structural differentiation and ambidexterity, in what conditions ambidexterity is most conducive to enterprise performance improvement, how to achieve ambidexterity and other issues.

\section{The Definition of Organizational Ambidexterity}

Since Duncan [4] first proposed the notion of organizational ambidexterity, scholars began to describe a series of organizational behaviors and outcomes using organizational ambidexterity. In fact, as Gibson and Birkinshaw [6] put it, organizational ambidexterity is increasingly understood as the ability of firms to do two different things at the same time, such as exploration and exploitation, efficiency and flexibility, and matching and adaptation. From the point of literature search view, the definition of organizational ambidexterity can be divided into three categories: structural ambidexterity, behavioral ambidexterity and realized ambidexterity. Structure ambidexterity and behavior ambidexterity refers to the process and mechanism of organization to achieve ambidexterity. The realization of ambidexterity means that the enterprise has realized a state of exploration and utilization of ambidexterity.

Structural ambidexterity refers to an organizational design or form that encompasses not only independent structural elements that engage in the exploration and utilization of activities, but also different capabilities, systems, incentives, processes, and cultures [7]. For example, upstream units (such as production) predominantly enjoy utilization activities, while downstream units (such as marketing and sales) are primarily responsible for exploration. These independent institutional units are shaped by the overall values, strategic intent and structural integration mechanisms of the business.

The behavioral perspective suggests that achieving organizational ambidexterity depends on the creation of a high-performance scenario within the enterprise that encourages employees to make autonomous decisions about the timing of exploration and utilization activities [8]. Thus, while the idea of structural ambidexterity is to create a binary structure within an enterprise to achieve organizational ambidexterity, the ethos of behavioral thinking is to create a series of well-designed systems and processes within the enterprise that define the behavioral situation of the members of the organization. In other words, the organizational situation allows individual members to simultaneously consider the exploration and utilization of the work undertaken. When individual members try to improve their work efficiency (doing the right thing), they also think about how to enhance the effect (doing the right thing).

Achieving ambidexterity is also the most common type of organizational ambidexterity that is based on organizational exploration and utilization activities that define organizational dichotomies such as dualistic organizations that successfully implement progressive and radical innovations [9]. Thus, the fundamental difference between the realized ambidexterity, structural ambidexterity and context ambidexterity is that it explicitly emphasizes the organization's performance in exploration and utilization activities. In this study, the structure and behavior dimensions refer to the orientation and attribute of the organization to promote ambidexterity, while the realization of ambidexterity refers to the implementation of the organization in the exploration and utilization activities. 
Table 1 Previous definitions of organizational ambidexterity

\begin{tabular}{|c|c|c|c|c|}
\hline Author & $\begin{array}{c}\text { Theoretical } \\
\text { / } \\
\text { empirical }\end{array}$ & $\begin{array}{l}\text { Levels/unit } \\
\text { of analysis }\end{array}$ & View & Definition \\
\hline Duncan ${ }^{[4]}$ & Theoretical & Business unit & Structural & $\begin{array}{l}\text { Capacity of organizations to } \\
\text { facilitate the differentiation of } \\
\text { organization structure that } \\
\text { facilitates the innovation process in } \\
\text { its two different stages. }\end{array}$ \\
\hline $\begin{array}{l}\text { Tushman } \\
\text { and } \\
\text { O’Reilly }\end{array}$ & Theoretical & Organization & Structural & $\begin{array}{l}\text { The ability to simultaneously pursue } \\
\text { both incremental and discontinuous } \\
\text { innovation and change that result } \\
\text { from hosting multiple contradictory } \\
\text { structures, processes, and cultures } \\
\text { within the same firm. }\end{array}$ \\
\hline $\begin{array}{c}\text { Benner } \\
\text { andTushma } \\
\mathrm{n}^{[7]}\end{array}$ & Theoretical & Organization & Structural & $\begin{array}{l}\text { Ambidextrous or dual organization } \\
\text { forms are organizational } \\
\text { architectures that build in both tight } \\
\text { and loose coupling simultaneously. }\end{array}$ \\
\hline $\begin{array}{l}\text { Gibson and } \\
\text { Birkinshaw } \\
{[6]}\end{array}$ & Empirical & Business unit & Behavioral & $\begin{array}{l}\text { Ambidexterity is the behavioural } \\
\text { capacity to simultaneously } \\
\text { demonstrate alignment and } \\
\text { adaptability across an entire } \\
\text { business unit. }\end{array}$ \\
\hline $\begin{array}{l}\text { He and } \\
\text { Wong }\end{array}$ & Empirical & Organization & Realized & $\begin{array}{l}\text { The need for an appropriate balance } \\
\text { between exploration and } \\
\text { exploitation . . . the capability to } \\
\text { operate in both mature markets } \\
\text { (where cost efficiency and } \\
\text { incremental innovation are critical) } \\
\text { and develop new products and } \\
\text { services for emerging markets } \\
\text { (where experimentation, speed, and } \\
\text { flexibility are critical). }\end{array}$ \\
\hline $\begin{array}{l}\text { Smith and } \\
\text { Tushman }\end{array}$ & Theoretical & Organization & Structural & $\begin{array}{l}\text { Ambidextrous designs are } \\
\text { organizational forms that build } \\
\text { internally consistent architectures } \\
\text { and cultures into business units so } \\
\text { that the firm can both explore and } \\
\text { exploit. }\end{array}$ \\
\hline$\underset{[10]}{\text { Danneels }}$ & Theoretical & Firm & Realized & $\begin{array}{l}\text { Firms that can develop and market } \\
\text { both sustaining and disruptive } \\
\text { innovations. }\end{array}$ \\
\hline Gupta et al. & Theoretical & Organization & Realized & $\begin{array}{l}\text { Ambidexterity refers to the } \\
\text { synchronous pursuit of both } \\
\text { exploration and exploitation via } \\
\text { loosely coupled and differentiated } \\
\text { subunits or individuals, each of } \\
\text { which specializes in either } \\
\text { exploration or exploitation. }\end{array}$ \\
\hline
\end{tabular}




\begin{tabular}{|c|l|l|l|l|}
\hline Author & $\begin{array}{c}\text { Theoretical } \\
\text { empirical }\end{array}$ & $\begin{array}{c}\text { Levels/unit } \\
\text { of analysis }\end{array}$ & View & \multicolumn{1}{c|}{ Definition } \\
\hline $\begin{array}{c}\text { Lubatkin } \\
\text { et al. }{ }^{[18]}\end{array}$ & Empirical & Organization & Realized & $\begin{array}{l}\text { Ambidextrous firms are capable of } \\
\text { exploiting existing competences as } \\
\text { well as exploring new opportunities } \\
\text { with equal dexterity. }\end{array}$ \\
\hline $\begin{array}{c}\text { O'Connor } \\
\text { and } \\
\text { DeMartino } \\
\text { 2] }\end{array}$ & Empirical & Business unit & Realized & $\begin{array}{l}\text { The ability of business unit } \\
\text { managers to simultaneously } \\
\text { advance radical innovation } \\
\text { initiatives while conducting daily } \\
\text { operational functions. }\end{array}$ \\
\hline $\begin{array}{c}\text { Venkatrama } \\
\text { n et al. } \\
\text { (2006) }{ }^{[13]}\end{array}$ & Empirical & Organization & Realized & $\begin{array}{l}\text { The capability of an organization to } \\
\text { simultaneously pursue exploration } \\
\text { of new product markets while } \\
\text { exploiting current product markets. }\end{array}$ \\
\hline $\begin{array}{c}\text { Bierly and } \\
\text { Daly }{ }^{[14]}\end{array}$ & Empirical & Organization & Realized & $\begin{array}{l}\text { Paradoxical companies that are } \\
\text { successful at simultaneous } \\
\text { exploration and exploitation. }\end{array}$ \\
\hline $\begin{array}{c}\text { Sidhu et al. } \\
\text { [15] }\end{array}$ & Empirical & Firm & $\begin{array}{l}\text { Firms that are able to manage } \\
\text { supply and spatial exploration with } \\
\text { demand-side exploitation in fast } \\
\text { changing dynamic contexts and to } \\
\text { juggle the balance so that they } \\
\text { combine demand and spatial } \\
\text { exploration with supply-side } \\
\text { exploitation when the environment } \\
\text { settles down. }\end{array}$ \\
\hline
\end{tabular}

\section{The Measurement of Organizational Ambidexterity}

At present, there is no unified caliber for the measurement of organizational ambidexterity. In general, scholars have measured ambidexterity primarily on the basis of an understanding of the balance and integration of ambidexterity [16]. Scholars based on the balance view believe that the implementation of two competing strategies at the same time put forward higher demands on internal resources, at this time what the companies need to do is how to compete between the two strategies to maintain a balance between organizational ambidexterity. Therefore, organizational ambidexterity is mainly measured by the absolute value of the difference of competing strategic behavior [17]. Based on the perspective of integration, scholars believe that the simultaneous implementation of two competing strategies will have an integrated (complementary) effect, so organizational ambidexterity is mainly measured by the product of competing strategic behavior [17]. In addition, scholars have proposed to measure the organizational ambidexterity by the sum of competing strategic behaviors [18], but this method is not supported by theorists.

\section{Conclusion}

Although interest in the concept of organizational ambidexterity has increased during recent years, this line of inquiry remains unfocused and limited due to a lack of more encompassing conceptual efforts. This paper explores the origin, definition and measurement of organizational ambidexterity. Organizational researchers are using ambidexterity, the ability of humans to use both hands with equal skill, as a metaphor for organizations that are equally dexterous at exploiting and exploring. 
Existing definition of organizational ambidexterity can be divided into three categories: structural ambidexterity, behavioral ambidexterity and realized ambidexterity. Scholars based on the balance view believe that organizational ambidexterity is mainly measured by the absolute value of the difference of competing strategic behavior, while scholars based on the integration view believe that organizational ambidexterity is mainly measured by the product of competing strategic behavior.

\section{Acknowledgement}

This research was financially supported by the National Natural Science Foundation of China (71502064).

\section{References}

[1] T. Burns, G.M. Stalker, The management of innovation, Tavistock, London, 1961.

[2] J .D. Thompson, Organizations in action: Social Sciences bases of administrative theory, McGraw-Hill, NewYork, 1967.

[3] J. March, Exploration and exploitation in organizational learning, Organization Science. 2(1991) 71-87.

[4] R. Duncan, The ambidextrous organization: Designing dual structures for innovation. In R. H. Killman, L. R. Pondy, \& D. Sleven (Eds.), The management of organization, 1 (1976) 167-188. New York: North Holland.

[5] M. L. Tushman, C. A. O’Reilly, The ambidextrous organization: Managing evolutionary and revolutionary change, California Management Review. 38(1996) 1-23.

[6] C. B. Gibson, J. Birkinshaw, The antecedents, consequences, and mediating role of organizational ambidexterity, Academy of Management fournal. 47(2004) 209-226.

[7] M. J. Benner, M. L. Tushman, Exploitation, exploration, and process management: the productivity dilemma revisited, Academy of Management Review. 28(2003) 238-256.

[8] Ghoshal, S. Bartlett, C, Linking organizational context and managerial action: The dimensions of quality in management, Strategic Management Journal. 15 (1994) 91-112.

[9] W. K. Smith, M. L. Tushman, Managing strategic contradictions: A top management model for managing innovation streams, Organization Science. 16 (2005) 522-536.

[10] E. Danneels, Dialogue on the effects of disruptive technologies on firms and industries, Journal of Product Innovation Management. 23(2006) 2-4.

[11] A. K. Gupta, K. G. Smith, C. E. Shalley, The interplay between exploration and exploitation, Academy of Management Journal, 49(2006) 693-706.

[12] G. C. O’Connor, R. DeMartino, Organizing for radical innovation: an exploratory study of the structural aspects of RI management systems in large established firms, Journal of Product Innovation Management. 23(2006) 475-497.

[13] N. Venkatraman, C. Lee, I. Bala, Strategic ambidexterity and sales growth: a longitudinal test in the software sector, Paper presented at the Academy of Management Meeting, Hawaii, August, 2006.

[14] P. E. Bierly, P. S. Daly, Alternative knowledge strategies, competitive environment, an organizational performance in small manufacturing firms, Entrepreneurship Theory and Practice, 31(2007) 493-516. 
[15] J. S. Sidhu, H. R. Commandeur, H. W. Volberda, The multifaceted nature of exploration and exploitation: value of supply, demand, and spatial search for innovation, Organization Science, 18(2007) 20-38.

[16] Z. He, P. Wong, Exploration vs, exploitation: An empirical test of the ambidexterity hypothesis, Organization Science. 15 (2004)481-494.

[17] Q. Cao, Z. Simsek, H. Zhang, Modelling the joint impact of the ceo and the tmt on organizational ambidexterity, Journal of Management Studies. 47 (2010) 1272-1296.

[18] M. H. Lubatkin, Z. Simsek, Y. Ling, J. F. Veiga, Ambidexterity and performance in small-to medium-sized firms: The pivotal role of top management team behavioral integration, Journal of Management. 32 (2006) 646-672. 